\title{
Stratocracy Theory of Governance and Development in Nigeria: Ex-President Olusegun Obasanjo Administrations as a Model
}

\author{
Alexandra Adetutu Oseni \\ Department of Public Policy, Southern University and A \& M College
}

\begin{abstract}
The study is quantitative in nature and involves hypotheses testing. This particular study is testing the stratocracy theory of government and development. Ratio scale variables were used for the data analysis. The researcher used paired sample t-test to compare the means of the different regimes under stratocracy system of governance. The paired sample t-test is used because the researcher is tasked to examine Olusegun Obasanjo's contribution to development at two different times. In other words, the researcher has two measurements (civilian and military) on the same item (stratocracy), and person (Olusegun Obasanjo). The paper used secondary sources of data from World Bank and other development journals and publications by grouping them based on the two different times of ruling (1976-1980 and 1999-2003). A sample of 10 periods was used in the analysis [i.e. 5 for each regime]. Two variables were used in the analysis, namely: (1) overall economic growth rates, and (2) healthcare expenditure as a percentage of GDP. As part of the study findings, the researcher fails to reject the stratocracy hypothesis with respect to the overall economic growth rates between the two different administrations [military or civilian] under Olusegun Obasanjo periods of governance. This implies that the type of Olusegun Obasanjo governance and his contribution to economic growth can be termed as stratocracy system of government. The researcher concluded that stratocracy is very important in ensuring economic growth because it is characterized by a political philosophy which holds that certain things, such as economic goods or power, should be vested in individuals on the basis of talent, effort, and achievement, rather than factors such as sexuality, race, gender, or wealth. This system of government needs to be promoted.
\end{abstract}

Keywords: Stratocracy, Governance, Development, GDP, Economic growth, and Healthcare Expenditure DOI: $10.7176 / \mathrm{IAGS} / 68-05$

\section{INTRODUCTION}

Stratocracy is a form of military government in which civil and military service are difficult to distinguish, where the state and the military are traditionally or constitutionally the same entity, and that government positions are always occupied by commissioned officers and military leaders (Bouvier and Gleason, 1999). Under the system of stratocracy, citizens with previous mandatory or voluntary military service, or veterans who have been honorably discharged, have the right to elect or govern (Bouvier and Gleason, 1999). The military's administrative, judiciary, and/or legislature powers are supported by law, the constitution, and the society, a typical case is observed under the Ex-president Olusegun Obasanjo. A stratocracy is considered as a form of meritocracy [a ruling or influential class of educated or skilled people or government or the holding of power by people selected on the basis of their ability]; it does not necessarily need to be autocratic or oligarchic by nature in order to preserve its right to rule to ensure development and growth in an economy (Young, 1958; Levinson,Cookson, and Sadovnik, 2002). It is very important to note that stratocracy is also characterized by a political philosophy which holds that certain things, such as economic goods or power, should be vested in individuals on the basis of talent, effort, and achievement, rather than factors such as sexuality, race, gender, or wealth. (Young, 1958; Levinson,Cookson, and Sadovnik, 2002). Advancement in such a system is based on performance, as measured through examination or demonstrated achievement (Young, 1958; Levinson,Cookson, and Sadovnik, 2002).

Economic growth and development are critical and essential components in Africans political discourse. Meanwhile, a country is classified as developed when is able to provide qualitative life for her citizenry. Nigeria's economy has once experienced remarkable growth over the past decade (Duru, 2002; Dodo, 2009; Okoye, 1985; World Bank, 2014). Sadly, this growth has neither reduced income inequality and poverty nor created greater employment opportunities. Growth empirics have argued that while economic growth is essential for development, there are also socio-political and human capital developments considerations that impact development (Ewegbemi, 2007; Dodo, 2009; Maier, 2008; World Bank, 2014).

Nigeria in the last fifty years has been battling with the problems of development in spite of huge human, material and natural resources in her possession (Duru, 2002; Dodo, 2009; Maier, 2008; Ajayi,1990; Okoye, 1985; World Bank, 2014). Considering the past five decades, Nigeria has experienced series of political leaders and numerous development plans, yet the country is still struggling with economic development as well as infrastructural development. Well, scholars such as Duru (2002); Dodo (2009); Maier (2008); and Ajayi (1990) have attributed the low performance of the Nigeria's economy in terms of development, growth, and sustainable good standard of living to the nature of the Nigerian state, the type and the nature of the political/ruling, the 
absence of structures, and dependency culture that has enveloped the nation politics. These scholars concurrently further emphasized that in the past, politics have been the main cosmetic avenue for official corruption, selfaggrandizement and represented at best occasional effusion of a highly distorted sense of national importance, achievement and exaggerated cohesion at the expense of the nation's development (Duru, 2002; Dodo, 2009; Maier, 2008; Ajayi,1990). Despite, the numerous postulations and theorization about factors that are likely to account for the low level of development in Nigeria and the claim of corruption, little is known about the empirical investigation of politics and development in Nigeria.

Very importantly, Ex-president Olusegun Obasanjo is an epitome of studying stratocracy of Nigeria's politics and development. He has enjoyed both military and civilian administrations in Nigeria at different periods. In February of 1976, there was an attempted coup by Buka Dimka, and though it was unsuccessful, but very bloody; Muhammed (the then president) was killed (Falola, Ihonybere, 1985; Meredith, 2005). Olusegun Obasanjo was chosen to take his place as the new military ruler, and promised to continue what Muhammed (civilian ruler) had started. During his term, he raised University fees, and this led to student riots (Falola, Ihonybere, 1985; Meredith, 2005). The government banned student organizations, restricted public opposition to the regime, controlled union activity, nationalized land, and increased oil industry regulation (Falola, Ihonybere, 1985; Meredith, 2005). However, in 1978, a new constitution was written that would return the country to civilian rule, and elections were held in 1979 and he was defeated (Falola, Ihonybere, 1985; Meredith, 2005). On March 1, 1995, there was another attempted coup by Lawan Gwadabe (Meredith, 2005). Also suspected as part of this coup were Olusegun Obasanjo and Shehu Musa Yar'Adua. Obasanjo Olusegun was jailed during Abacha's regime on charges of allegedly plotting against the Abacha's government, Obasanjo was supposed to serve a 25-year term. However, after the death of Abacha, he was released from prison by Abubakar, and Obasanjo was subsequently encouraged to run for president in the upcoming elections. After a series of primaries, Obasanjo was declared the new democratically elected president, and he was inaugurated as the new civilian president on May 29, 1999. This is the same person who was military dictator from 1976-1979. Obasanjo Olusegun took over as civilian president on May 29, 1999, he served until May 2007, when he handed over to Umaru Yar' Adua, his Vice President Goodluck Jonathan to continue after his death until May 292015 (Adeleke \& Gafar, 2012). Given the above narrative of Obasanjo Olusegun, he is indeed an epitome to be studied under stratocracy as a form of government. However, no current study has been used to examine the theory of stratocracy, which states that there is no different in civilian and military administration under a military leader. Therefore, this current study is purposed to examined this theory under Obasanjo Olusegun (military leader) different systems of ruling from 1976-1980 (military regime) and 1999-2002 (civilian). The question is there a difference in development of the Obasanjo Olusegun ruling for the two different periods of governance.

\section{METHODOLOGY}

The study is quantitative in nature and involves hypotheses testing. Ratio scale variables were used for the data analysis. The researcher used paired sample t-test to compare the means of the different regimes under stratocracy system of governance. The paired sample t-test is used because the researcher is tasked to examine Olusegun Obasanjo contribution to development at two different times. In other words, the researcher has two measurements (civilian and military) on the same item (stratocracy), and person (Olusegun Obasanjo). The groups are "paired" because there are intrinsic connections between them (i.e. they are not independent-based on the theory of stratocracy). The paper used secondary source of data from World Bank by grouping them based on the two different times of ruling (1976-1980 and 1999-2002). The variables used in the analysis are overall economic growth rates, and healthcare expenditure as a percentage of GDP.

The study was coded and analyzed with the help of SPSS 20.0. The data was presented and discussed with the help of charts, tables and p-values analysis. Since the researcher is exploring to test to see whether there is difference in the development indicators of the Obasanjo Olusegun ruling for the two different periods of governance. Prior to the computation of the statistical examination of the paired sample t-test, there is the need to state the hypothesis.

$\mathbf{H}_{0}$ : There is no significant difference in the development indicators under the Obasanjo Olusegun ruling for the two different periods of governance (stratocracy).

$\mathbf{H}_{1}$ : There exists a significant difference in the development indicators under the Obasanjo Olusegun ruling for the two different periods of governance [no stratocracy- easy to differentiate]. 
RESULTS

Table 1: Descriptive Summary of Olusegun Obasanjo Development Indicators under Stratocracy System of Governance

Statistics

\begin{tabular}{|c|c|c|c|c|c|}
\hline $\begin{array}{l}\text { Descriptive } \\
\text { Olusegun } \\
\text { Governance }\end{array}$ & $\begin{array}{r}\text { Summary of } \\
\text { Obasanjo }\end{array}$ & $\begin{array}{c}\text { Economic Growth } \\
\text { [1976-1980] }\end{array}$ & $\begin{array}{c}\text { Healthcare } \\
\text { Expenditure } \\
{[1976-1980]}\end{array}$ & $\begin{array}{l}\text { Healthcare } \\
\text { Expenditure } \\
{[1999-2003]}\end{array}$ & $\begin{array}{c}\text { Economic Growth } \\
\text { [1999-2003] }\end{array}$ \\
\hline & Valid & 5 & 5 & $\overline{5}$ & $\overline{5}$ \\
\hline & Missing & 5 & 5 & 5 & 5 \\
\hline \multicolumn{2}{|l|}{ Mean } & 6.4995 & 3.6460 & 5.8771 & 2.8052 \\
\hline \multicolumn{2}{|l|}{ Median } & 7.3187 & 3.8700 & 6.0600 & 5.2283 \\
\hline \multicolumn{2}{|l|}{ Mode } & $1.70^{\mathrm{a}}$ & $2.38^{\mathrm{a}}$ & $5.39^{\mathrm{a}}$ & $-2.63^{\mathrm{a}}$ \\
\hline \multicolumn{2}{|c|}{ Std. Deviation } & 2.75811 & 0.83829 & 0.39156 & 3.87097 \\
\hline \multicolumn{2}{|l|}{ Variance } & 7.607 & 0.703 & 0.153 & 14.984 \\
\hline \multicolumn{2}{|l|}{ Skewness } & -1.929 & -0.944 & -0.471 & -0.841 \\
\hline \multicolumn{2}{|c|}{ Std. Error of Skewness } & 0.913 & 0.913 & 0.913 & 0.913 \\
\hline \multicolumn{2}{|l|}{ Range } & 7.02 & 2.05 & 0.90 & 8.67 \\
\hline & 25 & 4.3695 & 2.8250 & 5.4629 & -1.2929 \\
\hline \multirow[t]{2}{*}{ Percentiles } & 50 & 7.3187 & 3.8700 & 6.0600 & 5.2283 \\
\hline & 75 & 8.2200 & 4.3550 & 6.2000 & 5.6916 \\
\hline
\end{tabular}

a. Multiple modes exist. The smallest value is shown

In all a sample size of 10 were used for the data analysis. The military regime ranges from 1976-1980 (5 years) and the first five years part of Obasanjo's civilian ruling ranges from 1999 to 2003 (5years). Two development indicators were used for the analysis: (1) overall economic growth rates, and (2) healthcare expenditure. This is observed in two different types of regimes under Olusegun Obasanjo administrations as illustrated in Table 1.

\section{Descriptive Analysis of Economic Growth for both Military and Civilian Rule Under Olusegun Obasanjo Stratocracy System of Governance:}

For the case of Economic Growth [1976-1980] under the military rule, the average growth rate between 1976 and 1980 is 6.4995 greater than the average economic growth rate of 2.8052 between 1999 and 2003 under Olusegun Obasanjo's stratocracy system of government. The median value (or $50^{\text {th }}$ percentile, or $2^{\text {nd }}$ quartile) of the economic growth rate between 1976 and 1980 [military rule] is 7.3187 greater than the median value (or $50^{\text {th }}$ percentile, or $2^{\text {nd }}$ quartile) of the economic growth rate of 5.2283 between 1999 and 2003 [civilian rule] under Olusegun Obasanjo's stratocracy system of government. The modal value of the economic growth rate between 1976 and 1980 is 1.70 greater than the modal value of the economic growth rate of -2.05 between 1999 and 2003. The standard deviation associated with the economic growth rate between 1976 and 1980 is 2.75811 smaller than the standard deviation of the economic growth rate of 3.87097 between 1999 and 2003 under Olusegun Obasanjo's stratocracy system of government. Additionally, the range associated the economic growth rate between 1976 and 1980 is 7.02 smaller than the range of the economic growth rate of 8.67 between 1999 and 2003 under Olusegun Obasanjo's stratocracy system of government. This implies that the economic growth rate data under the civilian rule [1999-2003] is widely spread or disperse away from the mean than the economic growth rate data under the military rule [1999-2003] data given the measurement with respect to the standard deviation and the range of the available information.

Regarding to the shape of the economic growth data for both military and civilian types of administration or ruling, the data is left skewed or skewed to the left. This is because the skewness values of the economic growth rate for 1976-1980, and 1999-2003 are -1.929 and -0.841 less than zero (or negative values) respectively. In terms of positions, about $25 \%$ of the economic growth rates values between 1976 and 1980 [military rule] representing the $1^{\text {st }}$ quartile (or $25^{\text {th }}$ percentile) is less than or equal to 4.3695 or $75 \%$ of the economic growth rates values are greater than or equal to 4.3695 . While, about $25 \%$ of the economic growth rates values between 1999 and 2003 [civilian rule] representing the $1^{\text {st }}$ quartile (or $25^{\text {th }}$ percentile) is less than or equal to -1.2929 or $75 \%$ of the economic growth rates values are greater than or equal to -1.2929 . For the case of the $75^{\text {th }}$ percentile or the $3^{\text {rd }}$ quartile; about $75 \%$ of the economic growth rates values between 1976 and 1980 [military rule] is less than or equal to 8.2200 or $25 \%$ of the economic growth rates values are greater than or equal to 8.2200 . While, about $75 \%$ of the economic growth rates values between 1999 and 2003 [civilian rule] less than or equal to 5.6916 or $25 \%$ of the economic growth rates values are greater than or equal 5.6916 . 
Descriptive Analysis of Healthcare Expenditure as Percentage of GDP for both Military and Civilian Rule Under Olusegun Obasanjo Stratocracy System of Governance:

For the case of healthcare expenditure as a percentage of GDP [1976-1980] under the military rule, the average healthcare expenditure as a percentage of GDP between 1976 and 1980 is 3.6460 smaller than the average healthcare expenditure as a percentage of GDP of 5.8771 between 1999 and 2003 under Olusegun Obasanjo's stratocracy system of government. The median value (or $50^{\text {th }}$ percentile, or $2^{\text {nd }}$ quartile) of the healthcare expenditure as a percentage of GDP between 1976 and 1980 [military rule] is 3.8700 smaller than the median value (or $50^{\text {th }}$ percentile, or $2^{\text {nd }}$ quartile) of the healthcare expenditure as a percentage of GDP of 6.0600 between 1999 and 2003 [civilian rule] under Olusegun Obasanjo's stratocracy system of government. The modal value of the healthcare expenditure as a percentage of GDP between 1976 and 1980 is 2.38 smaller than the modal value of the healthcare expenditure as a percentage of GDP of 5.39 between 1999 and 2003. The standard deviation associated with the healthcare expenditure as a percentage of GDP between 1976 and 1980 is 0.83829 greater than the standard deviation of the healthcare expenditure as a percentage of GDP of 0.39156 between 1999 and 2003 under Olusegun Obasanjo's stratocracy system of government. Additionally, the range [difference between the minimum and maximum values] associated the healthcare expenditure as a percentage of GDP between 1976 and 1980 is 2.05 greater than the range of the healthcare expenditure as a percentage of GDP of 0.90 between 1999 and 2003 under Olusegun Obasanjo's stratocracy system of government. This implies that the healthcare expenditure as a percentage of GDP data under the military rule [1999-2003] is widely spread or disperses away from the mean than the healthcare expenditure as a percentage of GDP data under the civilian rule [1999-2003] data given the measurement with respect to the standard deviation and the range of the available information.

Regarding to the shape of the healthcare expenditure as a percentage of GDP data for both military and civilian types of administration or ruling, the data is left skewed or skewed to the left. This is because the skewness values of the healthcare expenditure as a percentage of GDP for 1976-1980, and 1999-2003 are -0.944, and -0.471 less than zero (or negative values) respectively.

In terms of positions, about $25 \%$ of the healthcare expenditure as a percentage of GDP values between 1976 and 1980 [military rule] representing the $1^{\text {st }}$ quartile (or $25^{\text {th }}$ percentile) is less than or equal to 2.8250 or $75 \%$ of the healthcare expenditure as a percentage of GDP values are greater than or equal to 2.8250 . While, about $25 \%$ of healthcare expenditure as a percentage of GDP values between 1999 and 2003 [civilian rule] representing the $1^{\text {st }}$ quartile (or $25^{\text {th }}$ percentile) is less than or equal to 5.4629 or $75 \%$ of the healthcare expenditure as a percentage of GDP values are greater than or equal to 5.4629 . For the case of the $75^{\text {th }}$ percentile or the $3^{\text {rd }}$ quartile; about $75 \%$ of the healthcare expenditure as a percentage of GDP values between 1976 and 1980 [military rule] is less than or equal to 4.3550 or $25 \%$ of the healthcare expenditure as a percentage of GDP healthcare expenditure as a percentage of GDP values are greater than or equal to 4.3550 . While, about $75 \%$ of the healthcare expenditure as a percentage of GDP values between 1999 and 2003 [civilian rule] less than or equal to 6.2000 or $25 \%$ of the healthcare expenditure as a percentage of GDP values are greater than or equal 6.2000 .

Table 2: Pearson's Correlation Analysis of Olusegun Obasanjo Development Indicators under Stratocracy System of Governance

Correlations

\begin{tabular}{|c|c|c|c|c|c|}
\hline $\begin{array}{l}\text { Correlation of the } \\
\text { Development indicator } \\
\text { regimes }\end{array}$ & $\begin{array}{l}\text { Olusegun Obasanjo } \\
\text { s within the two }\end{array}$ & $\begin{array}{c}\text { Economic } \\
\text { Growth } \\
{[1976-1980]}\end{array}$ & $\begin{array}{c}\text { Healthcare } \\
\text { Expenditure } \\
{[1976-1980]}\end{array}$ & $\begin{array}{l}\text { Healthcare } \\
\text { Expenditure } \\
{[1999-2003]}\end{array}$ & $\begin{array}{l}\text { Economic } \\
\text { Growth } \\
\text { [1999-2003] }\end{array}$ \\
\hline \multirow{3}{*}{$\begin{array}{l}\text { Economic Growth } \\
\text { [1976-1980] }\end{array}$} & Pearson Correlation & 1 & 0.818 & 0.694 & -0.423 \\
\hline & Sig. (2-tailed) & & 0.091 & 0.194 & 0.478 \\
\hline & $\mathrm{N}$ & 5 & 5 & 5 & 5 \\
\hline \multirow{4}{*}{$\begin{array}{l}\text { Healthcare Expenditure } \\
\text { [1976-1980] }\end{array}$} & Pearson Correlation & 0.818 & 1 & $0.940^{*}$ & 0.167 \\
\hline & Sig. (2-tailed) & 0.091 & & 0.017 & 0.788 \\
\hline & $\mathrm{N}$ & 5 & 5 & 5 & 5 \\
\hline & Pearson Correlation & 0.694 & $0.940^{*}$ & 1 & 0.327 \\
\hline \multirow{2}{*}{$\begin{array}{l}\text { Healthcare Expenditure } \\
\text { [1999-2003] }\end{array}$} & Sig. (2-tailed) & 0.194 & 0.017 & & 0.591 \\
\hline & $\mathrm{N}$ & 5 & 5 & 5 & 5 \\
\hline \multirow{3}{*}{$\begin{array}{l}\text { Economic Growth } \\
{[1999-2003]}\end{array}$} & Pearson Correlation & -0.423 & 0.167 & 0.327 & 1 \\
\hline & Sig. (2-tailed) & 0.478 & 0.788 & 0.591 & \\
\hline & $\mathrm{N}$ & 5 & 5 & 5 & 5 \\
\hline
\end{tabular}

*. Correlation is significant at the 0.05 level (2-tailed).

Table 2 above illustrates the correlation analysis among the estimation variables. Regarding the correlation analysis between the economic growth rates [1976-1980] under military rule and healthcare expenditure as a 
percentage of GDP [1976-1980] under military rule, it was observe that there is a positive strong association or relationship between the two variables with a Pearson's coefficient value of 0.818 , which is also statistically significant at 10\% (0.10) significant level. On the other hand, the correlation analysis between the economic growth rates [1976-1980] under military rule and healthcare expenditure as a percentage of GDP [1999-2003] under civilian rule, appears to exhibit a positive moderate association or relationship between the two variables with a Pearson's coefficient value of 0.694 , which is not statistically significant at $10 \%(0.10)$ since the associated p-value $(0.194)$ is greater than $0.10,0.05$, and 0.01 . Additionally, the correlation analysis between the economic growth rates [1976-1980] under military rule and economic growth rates [1999-2003] under civilian rule appears to display a negative weak association or relationship between the two variables with a Pearson's coefficient value of -0.423 , which is not statistically significant at $10 \%(0.10)$ since the associated p-value $(0.478)$ is greater than $0.10,0.05$, and 0.01 .

For the case of healthcare expenditure as a percentage of GDP [1976-1980], the correlation analysis between the healthcare expenditure as a percentage of GDP [1976-1980] under military rule and healthcare expenditure as a percentage of GDP [1976-1980] under military rule, it was observe that there is a positive strong association or relationship between the two variables with a Pearson's coefficient value of 0.940, which is also statistically significant at $10 \%(0.10)$ significance level since the associated p-value $(0.017)$ is less than 0.05 , and 0.10

Finally, the correlation analysis between the healthcare expenditure as a percentage of GDP [1999-2003] under civilian rule and economic growth rates [1999-2003] under civilian rule appears to display a positive weak association or relationship between the two variables with a Pearson's coefficient value of 0.327 , which is not statistically significant at $10 \%(0.10)$ since the associated $p$-value $(0.529)$ is greater than $0.10,0.05$, and 0.01 .

Table 3: Hypothesis Testing Analysis-Paired Samples Test of Olusegun Obasanjo Development Indicators under Stratocracy System of Governance

Paired Samples Test

\begin{tabular}{|c|c|c|c|c|c|c|}
\hline \multirow{2}{*}{\multicolumn{2}{|c|}{ Paired Difference Test }} & \multicolumn{2}{|c|}{ Paired Differences } & \multirow[t]{2}{*}{$\mathrm{t}$} & \multirow[t]{2}{*}{$\mathrm{Df}$} & \multirow{2}{*}{$\begin{array}{l}\text { Sig. (2- } \\
\text { tailed) }\end{array}$} \\
\hline & & Mean & $\begin{array}{c}\text { Std. } \\
\text { Deviation }\end{array}$ & & & \\
\hline Pair 1 & $\begin{array}{l}\text { Economic Growth Between Military and } \\
\text { Civilian }\end{array}$ & 3.69438 & 5.62271 & 1.469 & 4 & 0.216 \\
\hline Pair 2 & $\begin{array}{l}\text { Healthcare Expenditure Between Military } \\
\text { and Civilian }\end{array}$ & 2.23114 & 0.48883 & 10.206 & 4 & 0.001 \\
\hline
\end{tabular}

Table 3 presents the hypothesis testing analysis of a paired sample t-test of Olusegun Obasanjo development indicators of overall economic growth, and healthcare expenditure as a percentage of GDP under the stratocracy theory of governance. For the case of the first paired analysis regarding the difference in overall economic growth between military and civilian rulings, there is a difference of 3.69438 in the means of the overall economic growth rate across the difference periods in Olusegun Obasanjo's administration. However, the paired difference test for the difference in the overall economic growth between the military [1976-1980] and civilian [1999-2003] is not statistically significant at 5\% (0.05) significance level, since the associated p-value of 0.216 is greater than $0.01,0.05$, and 0.10 . This implies that the researcher fails to reject the null hypothesis, which states that there is no significant difference in development under the Obasanjo Olusegun ruling for the two different periods of governance (stratocracy). Therefore, the researcher has strong evidence that the type of Olusegun Obasanjo administration and his contribution to economic growth can be termed as STRATOCRACY system of government by failing to reject the null hypothesis. Since it is difficult for the researcher to different between Olusegun Obasanjo military rulings from the civilian ruling given the economic growth indicator.

Alternatively, the healthcare expenditure as a percentage of GDP between military and civilian rulings has a difference in means of -2.23114 . The paired difference test for the difference in the healthcare expenditure as a percentage of GDP between military and civilian rulings is statistically significant at $1 \%(0.01), 5 \%(0.05)$, and $10 \%(0.10)$ since its associated p-value of 0.001 is less than $0.01,0.05$, and 0.10 . Therefore, the researcher has a strong evidence to reject the null hypothesis. This implies that the type of Olusegun Obasanjo administration and his contribution to healthcare expenditure as a percentage of GDP CANNOT be termed as STRATOCRACY system of government. The reason is that under the development indicator of healthcare expenditure as a percentage of GDP, it very easy for the researcher to difference the military and civilian rulings contribution to the healthcare expenditure as a percentage of GDP based on the statistical significant of the available data. The reason may include the fact that because health sector is a very critical area and involves a lot of professionals such as Doctors, nurses, pharmacists, and many others. They ensure that quality healthcare is provided for the citizens. Because of the nature of the job and things needed to discharge their duties, they easily threaten the government through series of strike actions, whenever the health sector is lacking the essential equipments and 
tools to be work with in order to provide quality healthcare to the citizens. This is one of the many reasons that make every government irrespective of the type of administration to treat the health sector with caution. So it makes it very easy to differentiate the political impacts on healthcare expenditure under the Olusegun Obasanjo political administrations.

\section{CONCLUSION}

Stratocracy system of government is observed under the Olusegun Obasanjo administration given the overall economic growth indicator. Economic growth and development indicators takes into account the composite of infrastructural, education, and health. Therefore, since the available data fails to reject the stratocracy hypothesis with respect to economic growth between the two different administrations [military or civilian] under Olusegun Obasanjo periods of governance. Therefore, the researcher can unambiguously conclude that the type of Olusegun Obasanjo administration and his contribution to economic growth can be termed as stratocracy system of government. Finally, stratocracy is very important because it is characterized by a political philosophy which holds that certain things, such as economic goods or power, should be vested in individuals on the basis of talent, effort, and achievement, rather than factors such as sexuality, race, gender, or wealth. This system of government needs to be promoted.

\section{REFERENCES}

Ajayi, I. (1990). The Trapped Economy (Nigeria: A Non-ideological Strategy for Self-reliance). Ibadan: Heinemann Educational Books.

Bouvier, J.; and Gleason, D. A. (1999). Institutes of American law. The Lawbook Exchange, Ltd. p. 7.

Duru, R.U. (2002). Poverty Alleviation Programme and Development of Small and Medium Scale Enterprises. Prospects for Poverty Alleviation in Rural Nigeria. Journal of Management and Development Studies 1(1): $159-163$.

Ewegbemi, O. (2007). Nigerian's Dependence on Oil: A Course on Economic Nationalism. http://www.dawondu.com/ewegbemi/htm

Falola, T., and Ihonvbere, J. O. (1985). The Rise and Fall of Nigeria's Second Republic, 1979-1983. London: Zed Books, 1985.

Levinson, D.; Cookson, P. W.; Sadovnik, A. R. (2002). Education and Sociology: An Encyclopedia. Taylor \& Francis. p. 436.

Maier, C.S. (2008). The Political Economy Approach. http://en.wikipedia.org/wiki/political-economy (Accessed 15 November, 2015).

Nzimiro, I. (1985). The Green Revolution in Nigeria or Modernization of Hunger. Lagos: Zim Pan-Africa Publishers.

Okoye, M. (1985). Even Development: Problems and Solutions. In: Nwosu, E.J. (ed) Achieving Even Development in Nigeria: Problems and Prospects. Enugu: Fourth Dimension Publishing Co. Ltd.

Oyimnatunba, C. (2008). Nigeria at 48: Still Perambulating and Groping for the Way. Lagos, Nigeria.

Young, M. (1958). The rise of the meritocracy, 1870-2033: An essay on education and inequality. London: Thames \& Hudson. 


\section{APPENDIX}

FREQUENCIES VARIABLES=Economicgrowthmilitary healthcareexpendituremilitary heathcareexpecivilian economicgrowthcivilian

/PERCENTILES=25.0 50.0 75.0

/STATISTICS=STDDEV VARIANCE RANGE MEAN MEDIAN MODE SKEWNESS SESKEW

/ORDER=ANALYSIS.

\section{Frequencies}

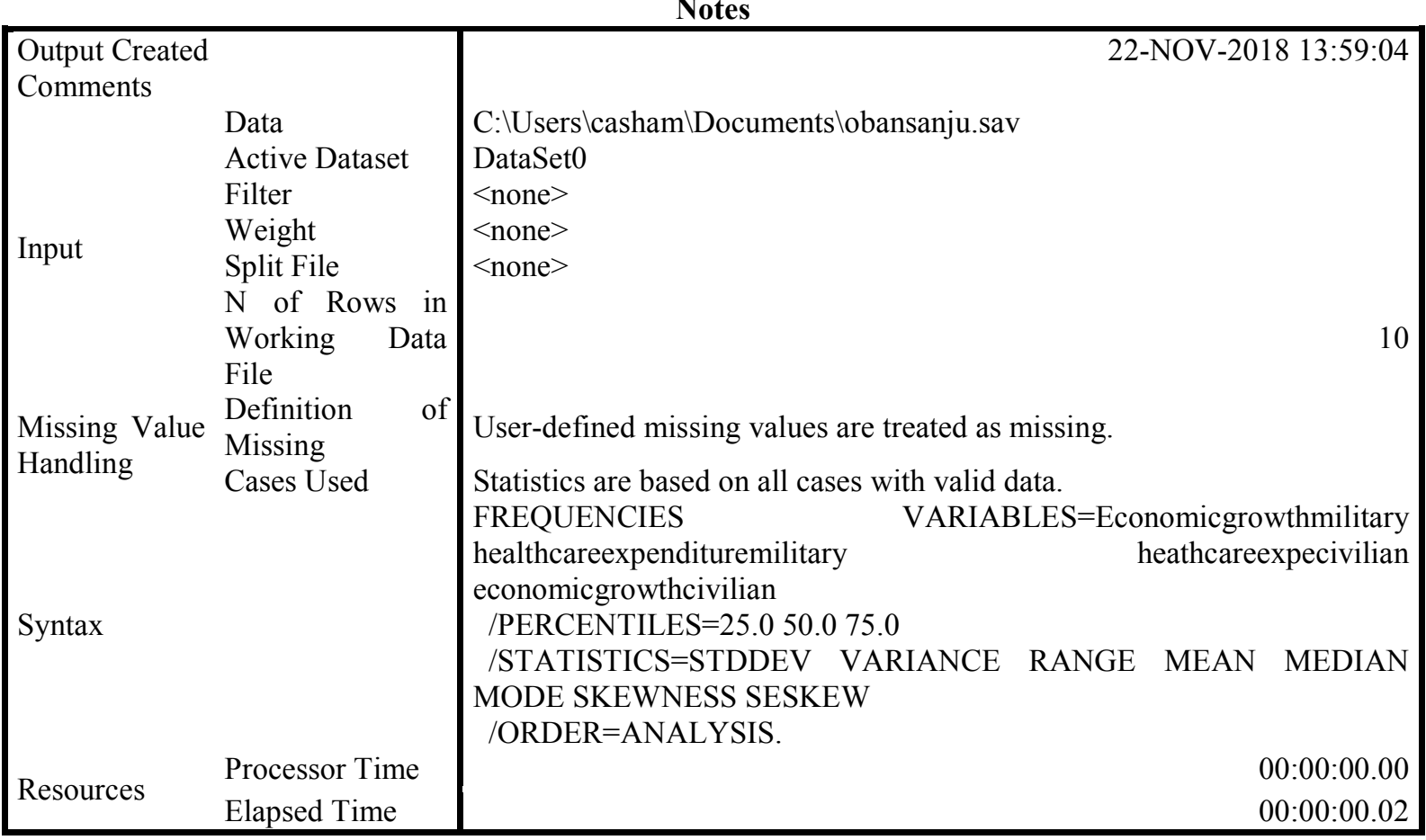

[DataSet0] C:\Users\casham $\backslash$ Documents\obansanju.sav

\section{Statistics}

\begin{tabular}{|c|c|c|c|c|c|}
\hline & & $\begin{array}{l}\text { Economicgro } \\
\text { wthmilitary }\end{array}$ & $\begin{array}{c}\text { healthcareexpendituremil } \\
\text { itary }\end{array}$ & $\begin{array}{l}\text { heathcareexpecivi } \\
\text { lian }\end{array}$ & $\begin{array}{l}\text { economicgrowthcivi } \\
\text { lian }\end{array}$ \\
\hline & Valid & 5 & 5 & 5 & 5 \\
\hline & Missing & 5 & 5 & 5 & 5 \\
\hline \multicolumn{2}{|l|}{ Mean } & 6.4995 & 3.6460 & 5.8771 & 2.8052 \\
\hline \multicolumn{2}{|l|}{ Median } & 7.3187 & 3.8700 & 6.0600 & 5.2283 \\
\hline \multicolumn{2}{|l|}{ Mode } & $1.70^{\mathrm{a}}$ & $2.38^{\mathrm{a}}$ & $5.39^{\mathrm{a}}$ & $-2.63^{\mathrm{a}}$ \\
\hline \multicolumn{2}{|c|}{ Std. Deviation } & 2.75811 & .83829 & .39156 & 3.87097 \\
\hline \multicolumn{2}{|l|}{ Variance } & 7.607 & .703 & .153 & 14.984 \\
\hline \multicolumn{2}{|l|}{ Skewness } & -1.929 & -.944 & -.471 & -.841 \\
\hline \multicolumn{2}{|c|}{ Std. Error of Skewness } & .913 & .913 & .913 & .913 \\
\hline \multicolumn{2}{|l|}{ Range } & 7.02 & 2.05 & .90 & 8.67 \\
\hline \multirow{3}{*}{$\begin{array}{l}\text { Percentil } \\
\text { es }\end{array}$} & 25 & 4.3695 & 2.8250 & 5.4629 & -1.2929 \\
\hline & 50 & 7.3187 & 3.8700 & 6.0600 & 5.2283 \\
\hline & 75 & 8.2200 & 4.3550 & 6.2000 & 5.6916 \\
\hline
\end{tabular}

a. Multiple modes exist. The smallest value is shown 


\section{Frequency Table}

Economicgrowthmilitary

\begin{tabular}{|rl|r|r|r|r|}
\hline & Frequency & Percent & Valid Percent & Cumulative Percent \\
\hline & 1.70 & 1 & 10.0 & 20.0 & 20.0 \\
& 7.04 & 1 & 10.0 & 20.0 & 40.0 \\
Valid & 7.32 & 1 & 10.0 & 20.0 & 60.0 \\
& 7.72 & 1 & 10.0 & 20.0 & 80.0 \\
& 8.72 & 1 & 10.0 & 20.0 & 100.0 \\
& Total & 5 & 50.0 & 100.0 & \\
Missing & System & 5 & 50.0 & & \\
Total & & 10 & 100.0 & & \\
\hline
\end{tabular}

healthcareexpendituremilitary

\begin{tabular}{|rl|r|r|r|r|}
\hline & & Frequency & Percent & Valid Percent & Cumulative Percent \\
\hline & 2.38 & 1 & 10.0 & 20.0 & 20.0 \\
& 3.27 & 1 & 10.0 & 20.0 & 40.0 \\
Valid & 3.87 & 1 & 10.0 & 20.0 & 60.0 \\
& 4.28 & 1 & 10.0 & 20.0 & 80.0 \\
& 4.43 & 1 & 10.0 & 20.0 & 100.0 \\
& Total & 5 & 50.0 & 100.0 & \\
Missing & System & 5 & 50.0 & & \\
Total & & 10 & 100.0 & & \\
\hline
\end{tabular}

heathcareexpecivilian

\begin{tabular}{|rl|r|r|r|r|}
\hline & Frequency & Percent & Valid Percent & Cumulative Percent \\
\hline & 5.39 & 1 & 10.0 & 20.0 & 20.0 \\
& 5.54 & 1 & 10.0 & 20.0 & 40.0 \\
Valid & 6.06 & 1 & 10.0 & 20.0 & 60.0 \\
& 6.11 & 1 & 10.0 & 20.0 & 80.0 \\
& 6.29 & 1 & 10.0 & 20.0 & 100.0 \\
& Total & 5 & 50.0 & 100.0 & \\
Missing & System & 5 & 50.0 & & \\
Total & & 10 & 100.0 & & \\
\hline
\end{tabular}

economicgrowthcivilian

\begin{tabular}{|rl|r|r|r|r|}
\hline & & Frequency & Percent & Valid Percent & \multicolumn{1}{c|}{ Cumulative Percent } \\
\hline & -2.63 & 1 & 10.0 & 20.0 & 20.0 \\
& .04 & 1 & 10.0 & 20.0 & 40.0 \\
Valid & 5.23 & 1 & 10.0 & 20.0 & 60.0 \\
& 5.34 & 1 & 10.0 & 20.0 & 80.0 \\
& 6.04 & 1 & 10.0 & 20.0 & 100.0 \\
& Total & 5 & 50.0 & 100.0 & \\
Missing & System & 5 & 50.0 & & \\
Total & & 10 & 100.0 & & \\
\hline
\end{tabular}




\section{CORRELATIONS}

/VARIABLES=Economicgrowthmilitary economicgrowthcivilian

$/$ PRINT=TWOTAIL NOSIG

/MISSING=PAIRWISE.

\section{Correlations}

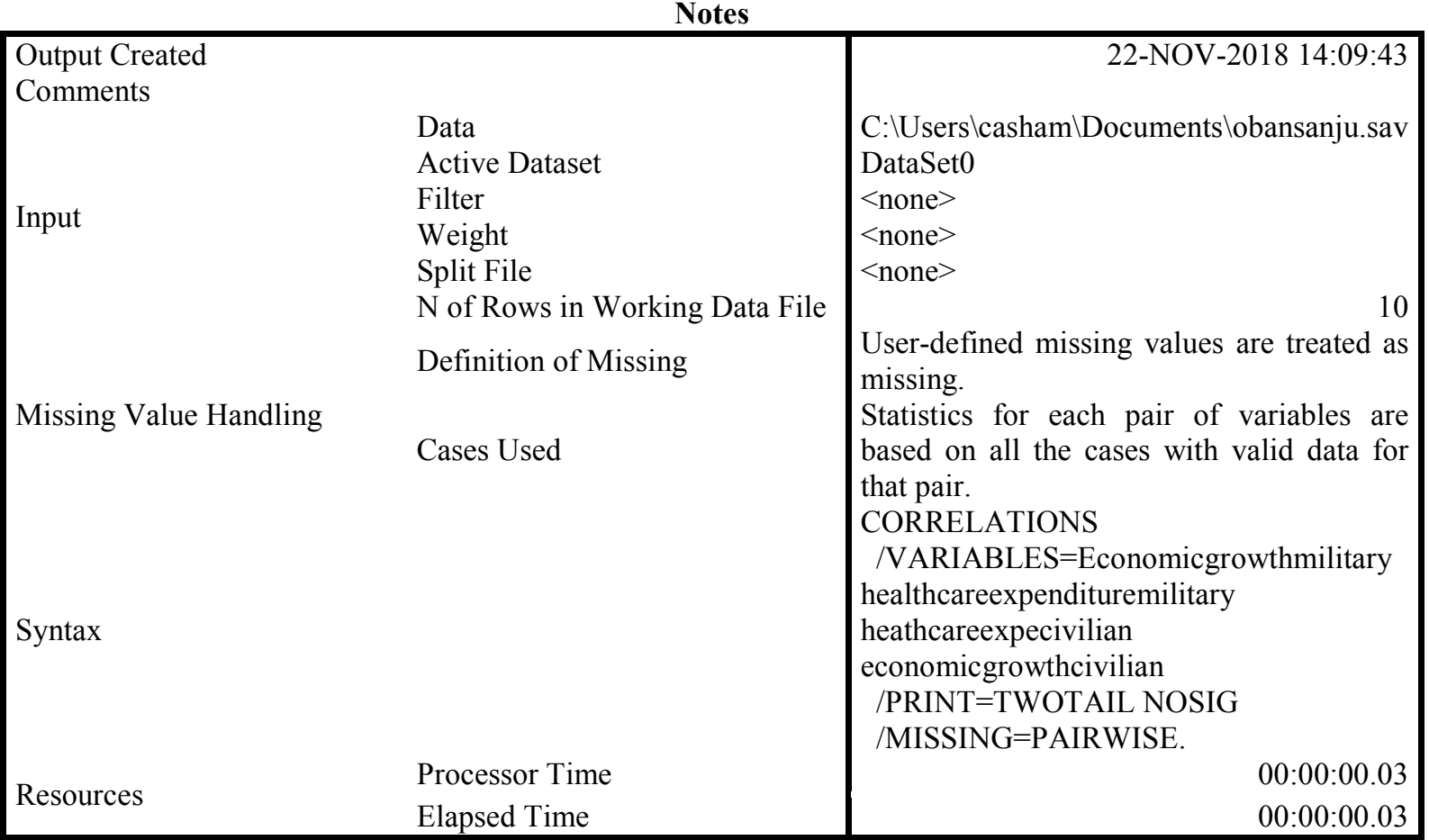

[DataSet0] C: $\backslash$ Users $\backslash$ casham $\backslash$ Documents $\backslash$ obansanju.sav

\section{Correlations}

\begin{tabular}{|c|c|c|c|c|c|}
\hline & & $\begin{array}{l}\text { Economicgrowth } \\
\text { military }\end{array}$ & $\begin{array}{c}\text { healthcareexpenditur } \\
\text { emilitary }\end{array}$ & $\begin{array}{c}\text { heathcareexpec } \\
\text { ivilian }\end{array}$ & $\begin{array}{l}\text { economicgrowth } \\
\text { civilian }\end{array}$ \\
\hline $\begin{array}{l}\text { Economicgrowt } \\
\text { hmilitary } \\
\text { Healthcareexpe } \\
\text { ndituremilitary } \\
\text { heathcareexpec } \\
\text { ivilian } \\
\text { economicgrowt } \\
\text { hcivilian }\end{array}$ & $\begin{array}{l}\text { Pearson } \\
\text { Correlation } \\
\text { Sig. (2-tailed) } \\
\text { N } \\
\text { Pearson } \\
\text { Correlation } \\
\text { Sig. (2-tailed) } \\
\text { N } \\
\text { Pearson } \\
\text { Correlation } \\
\text { Sig. (2-tailed) } \\
\text { N } \\
\text { Pearson } \\
\text { Correlation } \\
\text { Sig. (2-tailed) } \\
\text { N }\end{array}$ & $\begin{array}{r}1 \\
5 \\
5 \\
.818 \\
.091 \\
5 \\
.694 \\
.194 \\
5 \\
-.423 \\
.478 \\
5\end{array}$ & $\begin{array}{r}.818 \\
.091 \\
5 \\
1 \\
\\
5 \\
.940^{*} \\
.017 \\
5 \\
.167 \\
.788 \\
5\end{array}$ & $\begin{array}{r}.694 \\
.194 \\
5 \\
.940^{*} \\
.017 \\
5 \\
1 \\
5 \\
.327 \\
.591 \\
5\end{array}$ & $\begin{array}{r}-.423 \\
.478 \\
5 \\
.167 \\
.788 \\
5 \\
.327 \\
.591 \\
5 \\
1 \\
5\end{array}$ \\
\hline
\end{tabular}

*. Correlation is significant at the 0.05 level (2-tailed). 
T-TEST PAIRS=Economicgrowthmilitary healthcareexpendituremilitary WITH economicgrowthcivilian heathcareexpecivilian (PAIRED)

$/$ CRITERIA $=\mathrm{CI}(.9500)$

$/ \mathrm{MISSING}=\mathrm{ANALYSIS}$.

T-Test

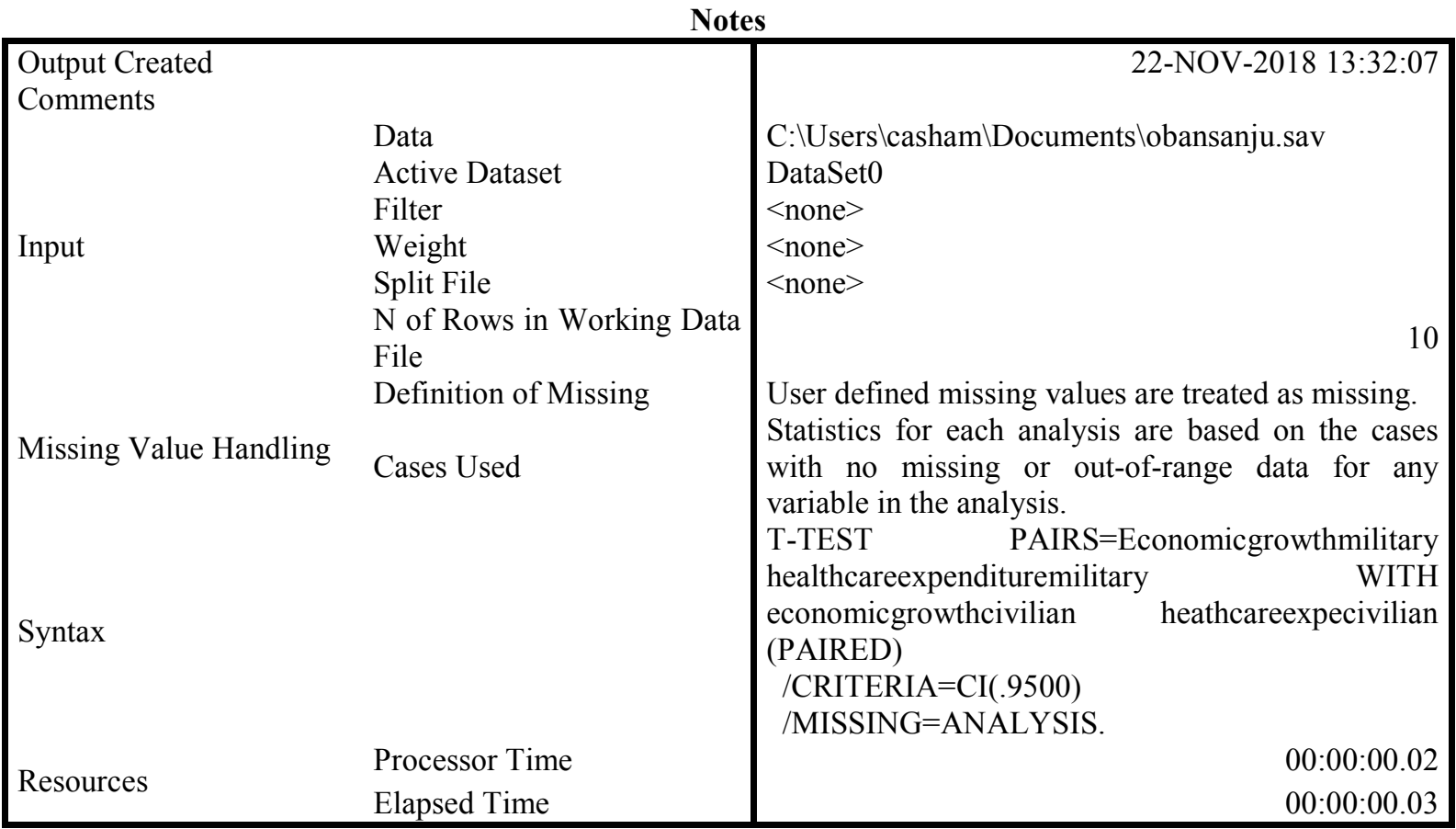

[DataSet0] C:\Users\casham \Documents\obansanju.sav

Paired Samples Statistics

\begin{tabular}{|ll|r|r|r|r|}
\hline & Mean & N & Std. Deviation & Std. Error Mean \\
\hline \multirow{2}{*}{ Pair 1 } & Economicgrowthmilitary & 6.4995 & 5 & 2.75811 & 1.23346 \\
& economicgrowthcivilian & 2.8052 & 5 & 3.87097 & 1.73115 \\
\multirow{2}{*}{ Pair 2 } & healthcareexpendituremilitary & 3.6460 & 5 & .83829 & .37489 \\
& heathcareexpecivilian & 5.8771 & 5 & .39156 & .17511 \\
\hline
\end{tabular}

Paired Samples Correlations

\begin{tabular}{|llr|r|r|r|}
\hline & & $\mathrm{N}$ & Correlation & Sig. \\
\hline Pair 1 & $\begin{array}{l}\text { Economicgrowthmilitary } \\
\text { economicgrowthcivilian } \\
\text { healthcareexpendituremilitary } \\
\text { heathcareexpecivilian }\end{array}$ & $\&$ & 5 & -.423 & .478 \\
Pair 2 & $\&$ & 5 & .940 & .017 \\
\hline
\end{tabular}

Paired Samples Test

\begin{tabular}{|c|c|c|c|c|c|c|c|c|}
\hline & \multicolumn{5}{|c|}{ Paired Differences } & \multirow[t]{3}{*}{$\mathrm{t}$} & \multirow[t]{3}{*}{$\mathrm{df}$} & \multirow{3}{*}{$\begin{array}{l}\text { Sig. (2- } \\
\text { tailed) }\end{array}$} \\
\hline & \multirow[t]{2}{*}{ Mean } & \multirow[t]{2}{*}{$\begin{array}{c}\text { Std. } \\
\text { Deviation }\end{array}$} & \multirow[t]{2}{*}{$\begin{array}{l}\text { Std. } \\
\text { Error } \\
\text { Mean }\end{array}$} & \multicolumn{2}{|c|}{$\begin{array}{l}95 \% \text { Confidence } \\
\text { Interval of the } \\
\text { Difference } \\
\end{array}$} & & & \\
\hline & & & & Lower & Upper & & & \\
\hline $\begin{array}{ll}\text { Pair } & \text { Economicgrowthmilitary } \\
1 & \text { economicgrowthcivilian } \\
\text { Pair } & \text { healthcareexpendituremilitary } \\
2 & \text { - heathcareexpecivilian }\end{array}$ & $\begin{array}{r}3.69438 \\
- \\
2.23114^{-}\end{array}$ & $\begin{array}{r}5.62271 \\
.48883\end{array}$ & $\begin{array}{r}2.51455 \\
.21861\end{array}$ & $\begin{array}{r}3.28714 \\
- \\
2.83811\end{array}$ & $\begin{array}{l}10.67589 \\
-1.62418\end{array}$ & $\begin{array}{r}1.469 \\
- \\
10.206 \\
\end{array}$ & 4 & $\begin{array}{l}.216 \\
.001\end{array}$ \\
\hline
\end{tabular}

